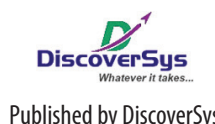

Published by DiscoverSys

\section{The determinants of early breast cancer detection via breast self-examination (BSE) in Denpasar, Bali}

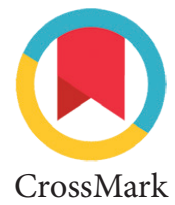

\author{
Ni Made Ari Febriyanti, ${ }^{1 *}$ Dinar Lubis, ${ }^{2}$ Dewa Nyoman Wirawan, ${ }^{2}$ \\ Ni Luh Putu Suariyani, ${ }^{2}$ Mangku Karmaya ${ }^{3}$
}

\section{ABSTRACT}

Background and purpose: Breast cancer is the leading cause of death in females, followed by colorectal cancer. Early detection of breast cancer can be done through breast self-examination (BSE). BSE behaviour is influenced by an individual's level of knowledge and perceptions of the procedure. This study examines the determinants of BSE behaviour in married women aged 15-49 in six villages in the working area of Puskesmas (public health centre) II in West Denpasar, Bali, Indonesia.

Methods: A cross-sectional survey was employed with 180 respondents selected by multistage random sampling. Data were collected using standardised questionnaire carried out from NovemberDecember 2016. Multiple poisson regression was used to identify the determinants of the BSE behaviours.
Results: The proportion of respondents who performed BSE in the three months prior to interview is $55.6 \%$, and, of these, $50.0 \%$ reported performing BSE regularly. Multivariate analysis shows the significant determinants of BSE are: high-school and above (APR=2.03; 95\%Cl:1.41 to 2.92); having a good knowledge of $B S E(A P R=1.41 ; 95 \% C l: 1.09$ to 1.82); perceived benefits ( $A P R=2$, 24; 95\%Cl:1.53-3.29); perceived low barrier (APR=1.63; 95\%Cl: 1.16-2.29); and high self-efficacy (APR=1.50;95\%Cl:1.16-1.95).

Conclusions: Level of education, good knowledge of BSE, perceived benefits, perceived low barriers, and high level of self-efficacy are the significant determinants of BSE practice. These findings suggest that education on BSE should be enhanced, particularly for women with lower levels of education.

Keywords: Breast cancer, breast self-examination (BSE), Bali

Cite This Article: Febriyanti, N.M.A., Lubis, D., Wirawan, D.N., Suariyani, N.L.P., Karmaya, M. 2018. The determinants of early breast cancer detection via breast self-examination (BSE) in Denpasar, Bali. Public Health and Preventive Medicine Archive 6(1): 37-41. D01:10.15562/phpma.v6i1.7

${ }^{1}$ Kartini Midwifery Academy Bali, ${ }^{2}$ Department of Public Health and Preventive Medicine, Faculty of Medicine, University of Udayana, ${ }^{3}$ Department of Anatomy, Faculty of Medicine, Udayana University

*Correspondence to:

Ni Made Ari Febriyanti, Kartini Midwifery Academy Bali,

febriari89@yahoo.com

\section{INTRODUCTION}

Breast-cancer is the most common cancer in women, affecting 43.1 women per 100,000 in 2012. ${ }^{1}$ The second, third, and fourth most common cancers are colorectal, cervical and lung cancers. ${ }^{1}$ In 2013, Indonesian Basic Health Research (Riskesdas) showed that the prevalence of all cancers in Indonesia was 1.4 per 1000 population, with Bali ranked third (2 per 1000), after Yogyakar ta (4.1 per 1000), and Central Java (2.1 per 1000). ${ }^{2}$ A 2014 report from the Bali Provincial Health Office showed that the total number of breast cancer cases in Bali was 192 cases per annum, with most cases (42\%) occurring in women aged $20-44 .{ }^{3}$

Early detection of breast cancer is vital in order to improve survival rates. ${ }^{4}$ An estimated $95 \%$ of women diagnosed and treated for breast cancer at an early stage can survive for more than five years after diagnosis and mortality can be reduced by $25-30 \% .{ }^{4}$ Breast self-examination (BSE) is a simple, cost-effective, and easy-to-perform method of detecting breast cancer. ${ }^{5}$ The Indonesian Government's BSE program has been running since 2008 and includes health initiatives such as counselling and promoting the importance of BSE, however, the proportion of women of reproductive age performing BSE remains low at $46 \%$ in $2016 .{ }^{6}$ This finding is supported by the results of a study carried out at Sanglah Hospital, Bali, which indicated that most $(68 \%)$ breast cancer patients first present with advanced stages of the disease. ${ }^{7}$ Such delays in seeking treatment are caused by several factors: patient's lack of knowledge about cancer and BSE, fear of a cancer diagnosis, economic factors and health insurance issues, belief in the efficacy of herbal medicine, lack of exposure to information about cancer, the level of support given by patient's husband and/or family, as well as the lack of effective BSE in women to aid the early detection of breast cancer. ${ }^{8,9}$

Previous study shows that effective BSE behaviour is influenced by several factors: individual's knowledge of breast cancer and BSE, family history of cancer, as well as the fear of cancer itself. ${ }^{10,11}$ BSE behaviour is also influenced by an individual's perceptions of BSE. For example, studies from Indonesia and Iran show a significant 
relationship between BSE's perceived benefits, the perceived barriers to performing BSE, and individual's level of self-efficacy, with the effective adoption of BSE. ${ }^{12,13}$ In addition to individual's perceptions, effective BSE behaviour is also influenced by women's skill level at performing BSE. ${ }^{14}$

The present study aims to identify the proportion and determinants of BSE practice among married women aged 15-49.

\section{METHODS}

A cross-sectional survey was employed in November-December 2016 with 180 married women aged 15-49 selected by multistage rando $\mathrm{m}$ sampling. Three villages were selected randomly from the six villages in the Puskesmas II West

Table 1 Characteristics of respondents and BSE practices

\begin{tabular}{lcc}
\hline Characteristics & $\mathbf{n}$ & $\%$ \\
\hline Age (years) & & \\
$<35$ & 57 & 31.67 \\
$\geq 35$ & 123 & 68.33
\end{tabular}

\section{Education}

$\leq$ Junior high school

$\geq$ High school

Family history of cancer

Yes

No

Performing BSE in the last three months

No

Yes

BSE frequency in the last three months $(n=100)$

Once
Twice
3 times
4 times
5 times
6 times
8 times

8 times

Reasons for irregular BSE $(n=71)$

No motivation

Consider BSE as unimportant

BSE not required because no symptoms

Other

Knowledge of BSE ( $n=100)$

Know how to perform BSE

Do not know how to perform BSE
Denpasar's working area. Eleven out of 23 hamlets (banjar) then randomly selected in the three selected villages. Finally, 180 respondents were selected by systematic random sampling from the list of married women aged 15-49 in these 11 banjar.

The questionnaire used in this study was pre-tested on 15 women with similar characteristics to this study's respondents. The questions on the perception-related variables were adapted from the questionnaire used in the Champion's Health Belief Model Scale (CHBMS). ${ }^{15}$ The researchers, assisted by six enumerators (who were trained prior to the interviews), carried out the data collection. Each respondent was provided with a verbal explanation of the study's aim and informed consent was requested in writing prior to each interview.

The dependent variable examined in this study is the reported practice of BSE over the past three months, while the independent variables consist of age, education, family history of breast cancer, knowledge of cancer, knowledge of the signs and symptoms of breast cancer and its prevention, perceived susceptibility to breast cancer, perceived seriousness of breast cancer, perceived benefits of BSE, perceived barriers to adopt BSE, and self-efficacy. The data were analysed using STATA SE 12.1 and multiple poisson regression to determine the factors associated with BSE practice. This study has obtained ethical approval from the Ethics Committee Faculty of Medicine, Udayana University/Sanglah General Hospital on 27th October 2016.

\section{RESULTS}

Table 1 shows the characteristics of the respondents and the proportion of BSE practice in the threemonth period prior to interview. Most respondents $(68.3 \%)$ aged $>35$ with the mean of age was 37.6 years; $67.2 \%$ had high-school education or above, and 91.7\% had no family history of breast cancer. The number of respondents who reported practicing BSE in the last three months prior to interview was $100(55.6 \%)$ but within this group, only 50 (50.0 \%) reported performing regular BSE during the past three months. Out of 100 respondents who reported ever practicing BSE in the last three months, the average frequency was 2.8 times (Table 3), with $24 \%$ had performed BSE once, $26 \%$ twice, $33 \%$ three times, and $17 \%$ four times or more.

Table 2 shows the association between BSE practices in the 3-month period prior to interview and some independent variables. There were significant associations between BSE practices with education $(\mathrm{p}<0.001)$, knowledge of BSE $(p<0.001)$, perceived benefits of BSE $(\mathrm{p}<0.001)$, perceived barriers to 
Table 2 Proportion of BSE practices by independent variables

\begin{tabular}{|c|c|c|c|}
\hline \multirow[b]{2}{*}{ Characteristics $(n=180)$} & \multicolumn{2}{|c|}{ Performing BSE } & \multirow[b]{2}{*}{ p value } \\
\hline & $\begin{array}{c}\text { No } \\
\text { n (\%) }\end{array}$ & $\begin{array}{c}\text { Yes } \\
\text { n (\%) }\end{array}$ & \\
\hline \multicolumn{4}{|l|}{ Age (years) } \\
\hline$<35$ & $27(47.37)$ & $30(52.63)$ & \\
\hline$\geq 35$ & $53(43.09)$ & $70(56.91)$ & 0.591 \\
\hline \multicolumn{4}{|l|}{ Education } \\
\hline$\leq$ Junior high school & $38(64.41)$ & $21(35.59)$ & \\
\hline$\geq$ High school & $42(34.17)$ & $79(65.29)$ & $<0.001$ \\
\hline \multicolumn{4}{|l|}{ Family history of cancer } \\
\hline No & $75(45.45)$ & $90(54.55)$ & \\
\hline Yes & $5(33.33)$ & $10(66.67)$ & 0.366 \\
\hline \multicolumn{4}{|l|}{ Knowledge of BSE } \\
\hline Poor & $73(55.73)$ & $58(44.27)$ & \\
\hline Good & $7(14.29)$ & $42(85.71)$ & $<0.001$ \\
\hline \multicolumn{4}{|l|}{ Perceived seriousness } \\
\hline Less serious & $68(47.89)$ & $74(52.11)$ & \\
\hline Feel serious & $12(31.58)$ & $26(68.42)$ & 0.072 \\
\hline \multicolumn{4}{|l|}{ Perceived vulnerability } \\
\hline Less vulnerable & $78(44.83)$ & $96(55.17)$ & \\
\hline Feel vulnerable & $2(33.33)$ & $4(66.67)$ & 0.577 \\
\hline \multicolumn{4}{|l|}{ Perceived benefits } \\
\hline Less useful & $53(70.67)$ & $22(29.33)$ & \\
\hline Feel useful & $27(25.71)$ & $78(74.29)$ & $<0.001$ \\
\hline \multicolumn{4}{|l|}{ Perceived barriers to BSE } \\
\hline There are barriers & $39(67.24)$ & $19(32.76)$ & \\
\hline No barrier & $41(33.61)$ & $81(66.39)$ & $<0.001$ \\
\hline \multicolumn{4}{|l|}{ Self-efficacy } \\
\hline Low & $69(58.47)$ & $49(41.53)$ & \\
\hline High & $11(17.74)$ & $51(82.26)$ & $<0.001$ \\
\hline Total & $80(44.44)$ & $100(55.56)$ & \\
\hline
\end{tabular}

BSE $(\mathrm{p}<0.001)$, and self-efficacy $(\mathrm{p}<0.001)$. There were no significant associations identified between BSE practices and age $(\mathrm{p}=0.591)$, family history of cancer $(\mathrm{p}=0.366)$, perceived seriousness of breast cancer $(\mathrm{p}=0.072)$, and perceived susceptibility to breast cancer ( $\mathrm{p}=0.577$ ).

Table 3 shows the average frequency of BSE among the 100 respondents who reported performing BSE in the three months prior to interview by the independent variables. There were significant mean differences of BSE frequency by education $(\mathrm{p}=0.001)$, knowledge of BSE $(\mathrm{p}=0.001)$, perceived benefits of BSE ( $p=0.002)$, perceived barriers to BSE $(p<0,001)$, and self-efficacy $(p=0.031)$. These findings were consistent to those in the association of BSE practice with the independent variables shown in Table 2.
Table 4 shows significant associations between BSE practices with education of highschool or above (APR=2.03;95\%CI:1.41-2.92), good knowledge of BSE (APR $=1.41 ; 95 \% \mathrm{CI}$ : 1.09-1,82), perceived benefits of BSE (APR $=2.24 ; 95 \% \mathrm{CI}: 1.53-3.29)$, perceived low barriers to BSE (APR=1.63;95\%CI:1.16-2.29), and high self-efficacy (APR=1.50; 95\%CI:1.16-1.95).

\section{DISCUSSION}

The proportion of respondents who reported performing BSE in the last three months prior to interview was $55.56 \%$. Among all respondents $(n=180), 50(27.8 \%)$ reported practicing BSE three times or more in the past three months. This means that only $27.8 \%$ of respondents performed BSE once per month as recommended. ${ }^{16}$ The reasons of respondents who reported performing BSE irregularly were lack of motivation and perceiving BSE as unimportant because of an absence of symptoms. This study also reveals that of the 100 respondents who reported performing BSE, only $40.0 \%$ practicing BSE with the recommended procedure.

Studies conducted in West Kalimantan and Central Java found that the proportions of respondents who reported performing BSE were $53.3 \%^{17}$ and $52.3 \%{ }^{12}$ respectively, although no time frames were mentioned. Therefore, the findings of the present study that show a higher uptake of BSE in Denpasar compared to West Kalimantan and Central Java could potentially because of the three months time period used as the time frame. The current study indicates the proportion of respondents who reported performing BSE routinely was $27.8 \%$. This finding was higher than the result of a study carried out in Banteran, Central Java, which found that only $17.2 \%$ of respondents reported performing BSE on a routine basis, while 33.3\% admitted performing BSE occasionally. ${ }^{18}$

This study found that respondent's education is a determinant associated with BSE practice $(\mathrm{APR}=2.03 ; 95 \% \mathrm{CI}: 1.41-2.92)$. This finding is consistent with the results of studies in Klaten ${ }^{10}$ and Central Java, ${ }^{12}$ which also reported that education is one of the determinants of effective BSE practice.

Furthermore, the present study also shows that good knowledge is an important factor of BSE practices (APR $=1.41 ; 95 \%$ CI: 1.09-1.82). This suggests that respondents with a good knowledge of breast cancer and its prevention are likely to perform BSE more frequently. The results of this study are consistent with other studies in West Kalimantan ${ }^{17}$ and South Kalimantan ${ }^{19}$ that also indicated a significant relationship between BSE uptake and knowledge. Meanwhile, other studies in Tanah Karo, North Sumatra ${ }^{20}$ and Turkey, ${ }^{21}$ also suggested an 
Table 3 Mean differences of BSE frequencies by independent variables

\begin{tabular}{|c|c|c|}
\hline Characteristics $(n=100)$ & Mean BSE frequency & p value \\
\hline \multicolumn{3}{|l|}{ Age (years) } \\
\hline$<35$ & 2.33 & \\
\hline$\geq 35$ & 3.00 & 0.326 \\
\hline \multicolumn{3}{|l|}{ Education } \\
\hline$\leq$ Junior high school & 1.76 & \\
\hline$\geq$ High school & 3.08 & 0.0011 \\
\hline \multicolumn{3}{|l|}{ Family history of cancer } \\
\hline No & 2.76 & \\
\hline Yes & 3.20 & 0.270 \\
\hline \multicolumn{3}{|l|}{ Knowledge of BSE } \\
\hline Poor & 2.47 & \\
\hline Good & 3.26 & 0.001 \\
\hline \multicolumn{3}{|l|}{ Perceived seriousness } \\
\hline Less serious & 2.84 & \\
\hline Feel serious & 2.69 & 0.946 \\
\hline \multicolumn{3}{|l|}{ Perceived vulnerability } \\
\hline Less vulnerable & 2.77 & \\
\hline Feel vulnerable & 3.50 & 0.812 \\
\hline \multicolumn{3}{|l|}{ Perceived benefits of BSE } \\
\hline Less useful & 1.82 & \\
\hline Feel useful & 3.08 & 0.002 \\
\hline \multicolumn{3}{|l|}{ Perceived barriers } \\
\hline There are barriers & 2.21 & \\
\hline No barriers & 2.94 & $<0.001$ \\
\hline \multicolumn{3}{|l|}{ Self- efficacy } \\
\hline Low & 2.45 & \\
\hline High & 3.14 & 0.031 \\
\hline Average frequency of BSE (in general) & 2.8 & \\
\hline
\end{tabular}

Table 4 Adjusted PR of determinants of BSE

\begin{tabular}{lccc}
\hline Variables & Adjusted PR & $\mathbf{9 5 \%} \mathbf{C l}$ & p value \\
\hline Education $\geq$ high school & 2.03 & $1.41-2.92$ & $<0.001$ \\
Good knowledge of BSE & 1.41 & $1.09-1.82$ & 0.009 \\
Perceived benefits of BSE & 2.24 & $1.53-3.29$ & $<0.001$ \\
Perceived low barriers to BSE & 1.63 & $1.16-2.29$ & 0.005 \\
High self-efficacy & 1.50 & $1.16-1.95$ & 0.002 \\
\hline
\end{tabular}

association between knowledge on early detection of breast cancer and BSE.

This study suggests that the perceived benefits of BSE, perceived low barrier to BSE, and high self-efficacy are significant determinants of BSE practices. Respondents with perceived benefits of
BSE, low barrier to BSE, and high self-efficacy tend to perform BSE routinely. These results are consistent with those of an Iranian study showing that perceived benefits of BSE and high self-efficacy are determinants of regular BSE. ${ }^{13}$

The present study indicates no significant association between BSE and family history of cancer. This finding is not consistent with the results of a study in South Kalimantan ${ }^{19}$ that suggested a significant association between family history of cancer and regular BSE. These different findings may be because only a very small proportion $(8.33 \%)$ of respondents in our study have a family history of breast cancer, while $45 \%$ of respondents in the South Kalimantan study reported family history of breast cancer.

Refer to the Health Belief Model, ${ }^{22,23}$ effective BSE practice is found to be significantly associated with perceived benefit, perceived barriers, and self-efficacy. However, BSE appears not to be associated with respondent's perceived seriousness and perceived susceptibility to breast cancer. This may be due to the weakness of the instrument used to measure these perceptions, as reported in a similar study in Hong Kong. ${ }^{24}$ Another limitation of this study is the limited area being covered, thus the generalization of the findings should be taken with caution.

\section{CONCLUSION}

The proportion of married women aged 15-49 who reported performing BSE is $55.56 \%$; meanwhile, the proportion of those who report performing BSE regularly in the three months prior to interview is $27.8 \%$. The variables determining the adoption of regular BSE are: education level, knowledge of breast cancer and its early detection, perceived benefits, perceived low barrier to BSE and high self-efficacy. The findings of this study reinforce the need for more widespread BSE campaigns combined with educational approaches to inform women about the risks of breast cancer and the importance of BSE; increasing their knowledge of BSE and promoting positive perceptions towards it.

\section{ACKNOWLEDGEMENT}

We would like to thank the Head of Public Health Center (Puskesmas) II, West Denpasar, the Heads of Dauh Puri Kelod Village, Dauh Puri Kangin Village and Dauh Puri Kauh Village, and all respondents who participated in this study. 


\section{REFERENCES}

1. International Agency for Research on Cancer. GLOBOCAN 2012: Estimated cancer incidence, mortality, and prevalence worldwide in 2012. IARC. France. 2012. Available at: http://globocan.iarc.fr/Pages/fact_sheets_ population.aspx (2012).

2. Ministry of Health of Indonesia. Riset Kesehatan Dasar 203 (The 2013 Indonesia Basic Health Research). Jakarta. Ministry of Health of Indonesia. 2014.

3. Bali Provincial Health Office. Laporan surveilans terpadu penyakit berbasis rumah sakit sentinel (kasus baru) (Integrated sentinel hospital based surveillance report of diseases). Denpasar. Bali Provincial Health Office. 2014

4. Indira. Ca Mammae (kanker payudara) (Breast cancer). Jakarta: Nuha Medika; 2010.

5. Nurcahyo, J. Awas bahaya kanker rahim dan kanker payudara (The impacts of cervical and breast cancers). Yogyakarta: Wahana Totalita Publisher; 2010.

6. Ministry of Health of Indonesia. Deteksi dini kanker payudara dengan SADARI dan SADANIS. (Early detection of brast cancer by breast self and clinical examinations). Jakarta. Ministry of Health of Indonesia. 2016. Available at: http://www.p2ptm.kemkes.go.id/kegiatan-p2ptm/dki-jakarta/deteksi-dini-kanker-payudara -dengan-sadari-dan-sadanis.

7. Hartaningsih NMD, Sudarsa IW. Kanker payudara pada wanita usia muda di bagian bedah onkologi Rumah Sakit Umum Pusat Sanglah Denpasar tahun 2002-2012 (Breast cancer among young women at the Department of Oncology, Sanglah General Hospital Denpasar, 20022012). E-Jurnal Medika Udayana. 2014; 3(6):1-13.

8. Rossalia N, Manuaba I. Faktor-faktor yang berhubungan dengan keterlambatan pengobatan pada penderita kanker payudara di Rumah Sakit Umum Pusat (RSUP) Sanglah (Factors associated with the late treatment among breast cancer patients at Sanglah General Hospital). Denpasar. E-Jurnal Medika Udayana. 2016; 5(12):1-7.

9. Dyanti G, Suariyani N.L.P. Faktor-faktor keterlambatan penderita kanker payudara dalam melakukan pemeriksaan awal ke pelayanan kesehatan (Factors associated with tha late detection of breast cancer at health services). Jurnal Kesehatan Masyarakat. 2016; 2(11):97-104.

10. Handayani, D.S. Hubungan antara tingkat pengetahuan dan sikap dengan perilaku para wanita dewasa awal dalam melakukan pemeriksaan payudara sendiri di Kelurahan Kalangan Kecamatan Pedan Klaten tahun 2008 [skripsi] (The association between knowledge and attitude with behavior of young adult women in breast self examination at Kalangan, Pedan Klaten Sub-District 2008 (undergraduate thesis)). Semarang: Universitas Diponegoro; 2008.

11. Wu CL and T-Y. The impact of breast cancer educational workshop on knowledge and breast self-examination practice among Korean-American Women. Journal of Nursing and Care 2004; 3(4):176

12. Desanti, I.M, Supriyati OI. Persepsi wanita berisiko kanker payudara tentang pemeriksaan payudara sendiri di Kota Semarang, Jawa Tengah (The perception of women with a high risk of breast cancer on breast self examination at Semarang City, Central Java). Jurnal Berita Kedokteran Masyarakat 2010; 26: 152.

13. Noroozi A, Jomand T, Tahmasebi R. Determinants of breast self-examination performance among Iranian women: an application of the health belief model . Journal of Cancer Education 2011; 26(2): 365-374.

14. Utari S, Anjarwati A. Pengaruh penyuluhan tentang deteksi dini kanker payudara terhadap keterampilan SADARI pada wanita usia subur di Dusun Klumprit Caturharjo Sleman [thesis] (The impact of early detection of breast cancer education on the skills of breast self examination among reproductive aged women in Klumprit Caturharjo Sleman (thesis)). Yogyakarta: Universitas Yogyakarta; 2012.

15. Champion V. Instrument refinement for breast cancer screening behaviors. Nursing Research. 1993; 42: 139-143.

16. Minsitry of Health of Indonesia. Buku saku pencegahan kanker leher rahim dan kanker payudara (Pocket book of cervical and breast cancers prevention). Jakarta: Ministry of Health of Indonesia; 2009.

17. Kurniawati, D. Hubungan pendidikan, pengetahuan dan sikap wanita usia subur (WUS) dengan pemeriksaan payudara sendiri (SADARI) di wilayah kerja Puskesmas Dara Juanti Kabupaten Sintang (The association between education, knowledge and attitude of reproductive aged women with breast self examination in Dara Juanti Public Health Center working area, Sintang District). Journal Stikes Kapuasraya. 2014; 1(2):15-27

18. Ekanita P, Khosidah A. Hubungan antara pengetahuan dan sikap WUS terhadap perilaku pemeriksaan payudara sendiri (SADARI) (The association between knowledge and attitude of reproductive aged women with breast self examination). Jurnal Publikasi Kebidanan. 2013; 4(2):167-177.

19. Handayani E. Hubungan pengetahuan dan riwayat penyakit keluarga dengan perilaku pemeriksaan payudara sendiri (SADARI) pada mahasiswi di Akademi Kebidanan Banua Bina Husada Banjarbaru Kalimantan Selatan Tahun 2016 (The association between knowledge and the family history of cancer with breast self examination among female students at the Midwifery Academy of Banua Bina Husada Banjarbaru South Kalimantan, 2016). Jurkessia. 2016; 4(3):40-45.

20. Karo, H. Analisa perilaku wanita usia diatas 20 tahun terhadap SADARI di lingkungan Kp. Baru Desa Cinta rakyat Kecamatan Merdeka Kabupaten Karo tahun 2014 [thesis] (Analysis of breast self examination among women over 20 years old in Baru Sub-Village, Cinta Rakyat Village, Merdeka Sub-District, Karo District, 2014 (thesis)). Medan: Universitas Sumatera Utara; 2014.

21. Dündar PE, Özmen D, Öztürk B, et al. The knowledge and attitudes of breast self-examination and mammography in a group of women in a rural area in Western Turkey. BMC Cancer 2006; 6: 43

22. Rosenstock, I.M, Strecher, V.J., Becker M.H. Social Learning Theory and The Health Belief Model. Health, Education\&Behaviour. 1974; 15 (2): 175-183.

23. Glanz, K., Rimer, B.K. \& Lewis, F.M. 2002. Health behavior and health education. Theory, research and practice. San Francisco: Wiley \& sons.

24. Fung SY. Factors associated with breast self-examination behaviour among Chinese woman in Hong Kong. Patient Education and Counseling 1998; 33: 233-243.

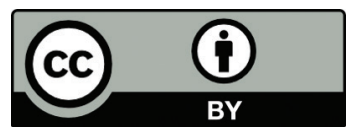

This work is licensed under a Creative Commons Attribution 